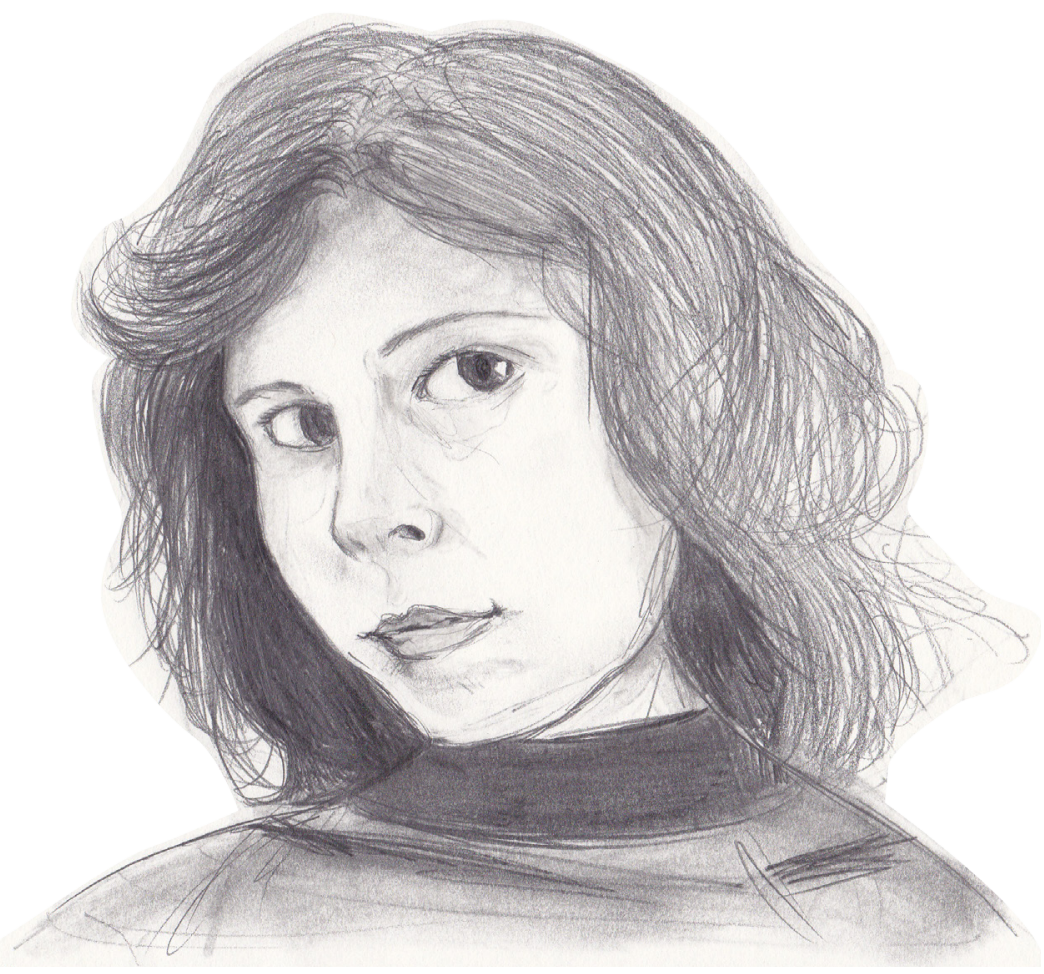

\title{
KAITLIN MILLER
}

Kaitlin Miller was born in Massachusetts and grew up in the Pittsburgh area. She is a sophomore studying Fiction Writing at the University of Pittsburgh. Minoring in the Studio Arts, she plans to illustrate her own writing. Her work has appeared in the Ralph Munn Creative Writing Anthology. With Penn's Woods as her backyard, she has a love of nature, especially poppies and willows, which helps her to persevere through her lack of a green thumb. 
FORBES \& FIFTH

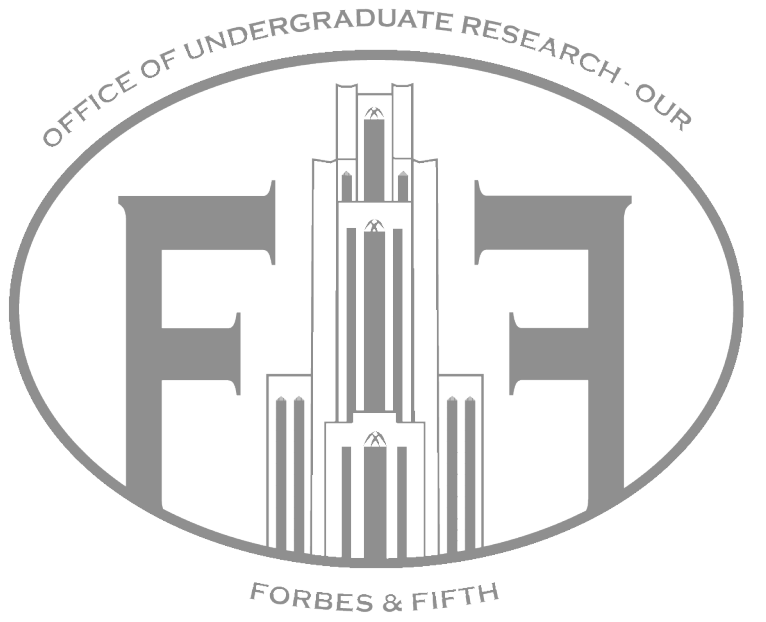




\section{Deadbeat Husband}

All I could see was red as I scrubbed the dishes. Ralph made me so mad sometimes and the fight we just had was tremendous. He refused to leave the room though... which irked me. He just stayed there - he wouldn't move no matter how many times I asked him, as politely as I could, to leave. He thought this was his room: he owned the house, he paid for it, so this was his room, and he didn't have to leave his room. That was how he rationalized it. I didn't own anything, not that chair I sat in or the celery I chopped for dinner. So... he didn't have to leave. That is, until the Bucks came on television.

I couldn't leave though; I had all these dishes to clean: plates, cups, forks, spoons, knives. It's not like Ralph was going to do it - so I had to. After the knives, there was the table (especially with all the food Ralph sprayed over my nice clean table cloth when he talked), the floor (of course with all the mud and sweat Ralph dripped and oozed and splashed when he came in from the fields at the end of the day - he never washed up before dinner), and the walls (where Ralph successfully smeared all his mud and sweat in an attempt to hold himself up, after all he was completely drunk... as usual).

All the while, as I cleaned up after his mess, Ralph just watched me. He knew I hated he was there so he did it simply to make me mad. If we hadn't gotten in a fight he would be in the den watching the pre-game as I got him another beer in between cleaning the spoons, but of course he wouldn't let the fight just die. Oh no... he had to stay there.

I tried not to look at him, my face growing blood red, but I could see his reflection in the smooth silver of the large knife I was washing I swear I saw him smile. He was enjoying this way too much and I was done. I screamed at him to "Get out!" but he wouldn't. In the end only the game drew Ralph out.

Walking across the kitchen floor I slipped and fell on the cupful of cranberry juice Ralph had knocked out of my hand during the fight. I didn't even bother getting up, it was too late and I was too tired: the red had already gotten all over my favorite dress. I would be lucky if it washed out, especially with the crappy cleaning detergent Ralph let me buy. It would have to be burned... that was that. I swore at myself and 
then reached up to the counter to get the soaking wet sponge, wringing it out first and then applying it to the sullied floor. Why did I even bother? I was his wife, that's why, and everything needed to be perfect (no matter his stinginess) - or he would get angry.

The cranberry juice had gotten farther than I had thought, but the room progressively got cleaner as I labored over it with a questionably old sponge and aching feet. By the time I was done and everything was back in order and sparkling, he was still spread out on the couch watching the game. My own blond hair covered in suds and a little cranberry juice, pale skin slightly moist from perspiration, and slender, calloused hands covered in muck, I slunk off to bed - making the easy decision not to disturb him - shrugged out of my now ruined dress, and snuck into the shower.

The hot water hit me like a horse tranquilizer; I hadn't realized how tense I had been down there. The steam that billowed out of the shower head as the boiling water battered the bottom of the bath filled my head and made me groggy, but that was how I wanted it. I didn't want to think about the fight we just had. Every time I almost forgot completely and let myself go, my eyes would

"Opening the door from the bathroom to the bedroom was war as the steam behind me clashed with the cold air that rushed in from the window." catch on the brown crud beneath my fingernails. Clinging as if to life itself, the grime refused to go away, embedding itself farther underneath the nail and deeper into my aggravated nerves. Scrub as I did, the filth did nothing but smile

up at me mockingly until I scrambled out of the shower, hands slipping and sliding over knobs and drawers, and procured the sharp tipped silver nail file out of my bedside table. Stabbing, slicing, and scraping, the instrument cleared away the dirt and finally, I found I could relax.

Opening the door from the bathroom to the bedroom was war as the steam behind me clashed with the cold air that rushed in from the window. My breath caught with the terrifyingly fast change from warmth to frigidity, eyes widening, mouth frozen open. Soon though, as I rigidly stepped forward onto the discolored shaggy carpet, the steam retreated into its own territory, dying quickly after, and I found my chest no longer incapable of movement. 
Without bothering to dress I collapsed onto the bed atop the covers, my raw, pink skin soaking the blankets beneath with wet from my dripping back. The nude flesh steamed and churned with cerise as the blood pitched just beneath the surface. I could feel the thump-thump throughout my body from toe to head as the blood pumped through my veins - pulsating as if one large blood vessel were being pushed along the path I naively chose: unforgiving, and with no breaks in sight. New bouts of cool air streamed in from the open night sky, passed through the fluttering shade, and pressed up against my form - holding me to the bed. The new chill licked at my inflamed flesh and caused all the hair on my body to prickle.

From my place on the bed I could see the dress Ralph had given me for our last anniversary still covered in cranberry juice and crumpled on the bureau, the dull light from the bathroom spotlighting the loving gift. Ralph had been so thoughtful in getting it for me, remembering how I looked at it in the store window as he got new tires from across the street. He really was a good man... Ralph. He was always looking after me and this little house, wearing himself away out in the fields every day. He had always done so much for me, and I knew I should try to do more for him in return, but sometimes I wondered whether it was enough. Would it ever be enough? I never did much right. It was always too dusty (which aggravated his allergies), or too dirty (he complained of living in squalor). Dinner was always too late or too early (which upset his delicate digestion), I didn't cook the meat right and gave him food poisoning. (I rightfully got sick myself and a good tap on the eye from Ralph.)

Tonight's fight wasn't really Ralph's fault. He didn't mean to knock me down this time (though I probably deserved it), he was just so frustrated with the crops this year. I knew now, after it was over and I had a chance to cool down, I shouldn't have blamed him for his attitude. He had a right to be upset... but I couldn't help myself, I was always so thoughtless with such an emotion-filled man. Poor Ralph felt everything, especially the pressure to keep me well provided for. Now what right did I have to scold him for that? It was my own temper really. I should have just let him vent — but I didn't, I couldn't, I had to press him, I had to make him angry. That was my fault.

I would have to make it up to him. From now on I would just 
have to try harder than I ever had. I would have to be a better wife.

The next morning the sun shone warmly on my face and all was dry, my aches soothed. A sound, though, kept tickling my eardrum - a low mumbling from downstairs that told me Ralph was up. Begrudgingly I rolled over to the side of the bed, Ralph's side cool and still made, and tugged out from my bureau a new dress, the one from last night still sleeping on the scuffed up wood.

Today would be better - I would be better.

Steps squeaked as I shuffled, still a bit drowsy, down the stairs, old wood grunting and rusty nails grinding, to make ready Ralph's breakfast. I had overslept, but so had Ralph as he still lay on the couch now watching the early morning run through of all the players and how they are expected to do in their upcoming games. "Morning," I offered guiltily to him as I walked by towards the kitchen, halting only for an instant to see if the gesture was well received. He didn't move. I stole into the kitchen.

The eggs and bacon sizzled and popped, grease flying into my hair and onto my face and hands, burning. The black coffee I poured was less potent but was still hot to the touch.

Sometimes I had wished I would pour it right in his lap and burn him even though I knew he would take it out on me, which of course I knew now he would have a right to.

Standing here with the coffee in my hands, jittering and splashing - I felt so ashamed. How could I have ever thought such horrible things? I couldn't help but think I was a horrible person, and it hurt because I had to admit to myself that it was true. With a mechanical fear, scared my thoughts were so dastardly that there was no way Ralph hadn't heard my sinful mind, I looked up over the couch at his open form — Ralph didn't move.

-Of course he hadn't heard.

He couldn't have.

Right?

What if he read it on my face when he saw me?

What if he saw the wicked, dirty thought? 
There was a slight knocking, my hands jittering, as the tray hit the side table to the left of the old couch. The love seat was caved in on one side from too much use and ripped on the other from a mean old dog with a lazy eye Ralph brought home one year and called Rusty.

Ralph was always so kind to animals, but this one was just purely in contradiction to our Lord. Someone must have been on my side as the nasty dog died the next year from an unsecured pitchfork in the barn. Either way, the knocking only seemed to irritate Ralph, and he simply refused to eat anything. I was just glad he hadn't puked all side as the nasty dog died the next over the carpet like that one time last year. That took all day to clean out and I still couldn't get what was

"Ralph was always so kind to animals, but this one was just purely in contradiction to our Lord. Someone must have been on my year from an unsecured pitchfork in the barn." left of the faded stain off, no matter how hard I tried. He did try to apologize though by bringing in some daisies from the petite garden he gave me as a present when we first moved in.

In the end, the cold breakfast sitting on the table, I brought down some blankets and a pillow from upstairs as he was too tired to get up. I didn't bother bringing him anything else for the rest of the day but his black coffee (which always succeeded in sobering him up after a hard night). At the end of the day I was going to draw him a hot bath, but when I went in I saw he had somehow already taken a shower while I was cleaning. How he did it with one of his hangovers was beyond me. Either way the bath was covered in dirt and grime and other such matter to make your stomach twirl. I would have to clean it sometime, but not now. I didn't want to disturb him. Instead I went downstairs and started dinner.

The next day Ralph felt better (God knows with that much sleep he should have) but he still was too tired to get ready by himself. I ended up helping him. After that I made a breakfast for two and walked with him to the door as he went off to the fields and the fresh set of crops he was to pick for market.

We weren't a big farm, only me and him, but it kept us going. 
When we originally started out, there was supposed to be a son, but that never worked out - nothing had worked out the way I planned, but I was still happy with my life with Ralph. Just then I wondered if Ralph knew I was happy with him. I had always just assumed he had. I thought it was one of those unsaid matters...

By the time Ralph got home his skin had turned ice cold and white as a sheet. He had also forgotten the corn which I'd asked him to bring back for tonight's meal. I couldn't bear him to do it in his condition so after taking him inside and getting him some water I went out and got the corn myself. It might have been a little drier than usual, but it was food, and there wasn't an abundance of that around here... despite the setting of a farm house. After that, dinner went fine. Ralph was much quieter than usual (I found I had to provide much of the conversation) but that was very welcome after the previous debacle. I made sure his plate was always filled and his cup overflowing, he was always happier when full.

Soon our house seemed to go into a lull, which was quite calming. The days passed on quietly with the moon and sun; Ralph didn't complain much at all about his work... and as a matter of fact neither did I. Things seemed to become easier. I became better at cleaning up after him, and I wasn't getting as much beer for the fridge so I knew he wasn't drinking as much. Maybe, I thought to myself, maybe that night got to him. Maybe he is trying to be better too. A slight smile lifted the sides of my mouth.

I was interrupted though with a knock at the door which I promptly answered. It turned out to be an employee from the market a good while down the road that we sold our crops to.

"Oh, hello there, Mrs. Frank, I am so sorry to disturb you, but is Mr. Frank here today?"

"Mr. Stein, today is Sunday, the Lord's day. I am afraid Mr. Frank cannot do business today. You might come back at a later, more appropriate, date."

"I am sorry for such an inconvenience ma' am, but I was looking over the records and I noticed that your husband has not brought by his 
usual produce to," he stopped her for a second and flashed me a salesman's smile, "your friends down at 'Al's Food.",

I eyed him over with a stern gaze and a hand on the doorknob. "We are God fearing people, Mr. Stein. My husband is worshipping the Lord today - as should you. I am afraid he simply must not be disturbed. Now you have a good day and I will speak with my husband on the matter later." With that I curtly smiled at the rude interruption of our day of rest and prayer - along with my worries - and closed the door. I would speak with him tomorrow. This was God's day, not mine.

I knew I shouldn't speak business but what the man said just kept boring a hole deeper and deeper into my mind until I could think of nothing else. Why hadn't Ralph been delivering the crops? What has he been doing out there? Have the crops died somehow? By the end of the night, after I helped him undress and into bed (as was customary of late) I couldn't keep silent any more. The questions were too much.

Lying down in bed I turned away from him and pulled the rough covers up to my shoulders. I wasn't exactly sure where to start so I unassumingly brought up Mr. Stein's visit. I didn't want to start anything; we had been getting along so much better.

"Mr. Stein dropped by today dear."

Silence.

"He mentioned something that bothered me."

He still didn't say anything.

"Mr. Stein says you haven't been delivering the crop lately."

Again there was silence, so I turned over to look at him. His eyes were almost blank which gave me very little to read in them.

"Why haven't you been delivering the corn?" I spoke a little more forcefully. I knew I shouldn't have, to keep the peace, but his quiet was angering me. That was our livelihood and it seemed to be going to the dogs for all he was telling me!

Still Ralph stayed mute, just staring out the windows in the direction of the crop field.

"Fine," I said curtly. "I'll go find out myself." I only hoped there would be some explanation which didn't implicate dear Ralph. In the dark depths of my mind, though, I couldn't help but think of how calm Ralph had been lately, and the stash of liquor he had hidden in the barn. 
Brusquely I pushed off the bed, threw on a pair of blue-jeans, and jumped in the truck. The engine roared to life and I took off, headlights clearing a path as I made a bee-line to the fields. The lumpy dirt and chunks of rock beneath the tires of the car made the high-speed drive a bumpy one, tossing me up and down as I drove. A couple times my head got a little too close for comfort to the roof of the car, which would not exactly have been forgiving. Finally though, through dust and over rocks and into the darkness I reached the cornfields where I set the beams on high and shone them on where the corn should have been.

My breath caught in my throat. Everything was withered and dead as far as I could see with the aid of the high beams. How could this be happening? How could Ralph let this happen?! I knew he had been angry about the terrible crops this season during our fight, but when he became so calm I assumed they had been getting better. Was he truly lying back in the barn all day, drinking? Was that why he was so relaxed recently?

This red anger made the trip back faster than the trip there, and with a few more bumps where I actually did hit my head on the roof of the truck. It didn't matter to me now though; all that mattered was what I saw out there in the fields. I slammed the door as I ran, livid, into the house, crashing up the stairs and into

"Everything was withered and dead as far as I could see with the aid of the high beams." the bedroom. "What have you been doing?!" I shrieked at him. Ralph was still lying in the bed, staring out the window. Standing between him and the window I forced him to look at me. "Why are all the crops dead?! Have you been drinkin' all day? I have allowed that little stash of yours in the barn — but if this is what you're doin' with it — loungin' around all day drinkin' - well I'm just gonna to have to take it away!"

He stayed quiet, which stunned me for a man of his temper. I found I couldn't speak either, and as I stood there in silence I took a moment to think, for the first time, and my head and anger began to clear for a calmer vantage. Instead of screaming again I padded quietly over to him and knelt down at the bedside, thinking of how much I loved Ralph and how he would never purposefully hurt me and our life together, and for a moment I thought I saw tears at the edges of his eyes. 
“The crops just failed this year, didn't they? You tried your best and they failed and here I am yellin' at you. Oh dear I am so sorry. Please forgive me." I placed my hand in his and crawled over him to my side of the bed where he turned to face me.

Ralph gazed at me in his own special way and I smiled over at him in return - we were okay again. Moving over I snuggled against his body, clean and still lukewarm from the bath he had taken, and I wrapped his arm around me. It was comforting to feel his chest against my back, but his chest bones were just so harsh to my flesh. I knew he hadn't been eating as much, but I hadn't known why. Now I understood it was probably worry over the bad crops this season. He was just trying to protect me from the truth.

"You should start eatin' more, you're skin and bones," I spoke softly, dragging my finger across his sunken chest. His pale face looked almost milky in the moon light. "We can afford it, the next crop will go better, you'll see. Not eatin' won't do you any good when you have to work out there. You're just gettin' paler and paler. Tomorrow I will make you a good hearty breakfast and you won't worry about a thing. Okay?" Ralph didn't say anything but I knew he had given in to me. He knew that when I set my mind on something I would not give up.

The next week was pretty quiet. I took care not to mention the crops, though he did notice I was a little more careful with the leftovers and the market money, and when he got home I bathed him and cooked him a warm meal to fill his stomach after his hard day's work. I didn't mention it to him, but I was beginning to get nervous. The money was running out and I could feel winter in the air. We wouldn't have money enough for food let alone firewood, and this rickety old house couldn't keep the heat in at all. How were we going to survive?

Thursday night was the coldest so far - I could see my breath by the moon's light as I lay in bed with him. This couldn't be good for his condition at all. Ralph had gotten a cold over the past couple days and I was simply beside myself with worry. He barely ate anything, he was pale as a sheet, and no matter how many times I asked him to stay in bed and let it pass, he simply insisted on going out.

Wiggling closer to him, my calf brushed against one of his toes and I couldn't believe how icy it was. It couldn't be healthy. I worried he 
might get frostbite and told him to put on some socks, but he was too tired to get up and, honestly, so was I.

As I cleaned up after breakfast, washing all the plates, bowls, forks, spoons and knives, I realized that wasn't the only bad event that was going to occur that Friday. Over the scrubbing of the knives and the sloshing, whooshing, and splattering of the water, I heard the ominous sound of a car puttering up the driveway. Nervous, I swished open the curtains, almost cutting them with the knife, and saw, just driving up to the house, an undersized, chunky car with a miniature, greasy haired, brown suited man bouncing around on the inside like a rubber ball.

Taking a deep breath I clenched my fists and marched out to meet the man.

"Mr. Stein." A controlled smile touching my lips.

"Mrs. Frank." He paused. "So nice to see you again. I made it a point this time not to show up on Sunday as you might have noticed."

"I certainly did."

"Would I be able to speak with your husband today ma'am? It is most urgent now, you see, as it is getting late and many of your happy customers have become quite impatient. They just cannot wait to taste your sweet, mouth-watering corn."

"Well, I would let you see him, but as it is he's out workin' at the moment. You just missed him." I couldn't let him talk to my poor husband; it would only upset him having to admit such a loss. These people would just have to wait.

At this the man's politeness seemed to crack - jaw clenching, mouth twisting slightly, fingers reaching up and clawing at his stiff hair, eyes straying across the property and around the house - that is, until his eyes alit on something I didn't see. Then a wide, sleazy smile cut in half his plastic face and his fingers mechanically reached up and patted down his messed up hair. "There your husband is right now, Mrs. Frank. I'll just go talk to him." Then before I got a chance to stop him he shot off in the direction he claimed he saw Ralph. Mr. Stein must have been lying though, because Ralph left for the fields an hour ago. I began to follow Mr. Stein to wherever he was heading.

"Now you just come on back, ya hear?! Mr. Stein?! You have no right-," then something cut me off. 
It was Mr. Stein's hollering that did it (God, I hoped he didn't get injured on some of our farm equipment. The pitch fork made me extremely uneasy, especially the way it fell off and skewered Rusty... that damn dog made such a mess of my garden and such a splattering on the barn floor).

Running around the corner of the house, I saw Mr. Stein stopped right before Ralph's truck. "Now I told you not to disturb my husband! You have no right bein' on our property!" As I got nearer my voice got lower and calmer, like how one would explain something to a child. "If you must know... we had a bad year with

"The man's breath became ragged and his jaw began to work up and down, but no sound came out." the corn, that's all. It's not my husband's fault. He did the best he could."

There was no response.

Walking around to the other side of Mr. Stein so that I was in between him and the truck I stared him right in the face. It was the most peculiar thing though. He was completely drained of color and his eyes were pried open like he was looking at the devil himself. "Now what are you starin' at my husband for, Mr. Stein?" I ordered.

The man's breath became ragged and his jaw began to work up and down, but no sound came out.

"I asked you a question, Mr. Stein, and I expect you to answer it."

"Whuh- whuh-," he began to breath. Then he turned to me, eyes wide, brow crinkled.

"Why are you gawkin' at my Ralph like that? He ain't a ghost. It's very, very rude."

He raised a finger at Ralph and then at me.

"It's also rude to point, Mr. Stein. I'm sure your momma taught you that."

"You. You-," he paused. "Jesus Christ." Mr. Stein swore breathlessly as he outright stared at poor Ralph.

"Now it's not nice to use our Lord Jesus Christ as a swear word, Mr. Stein, and I will not stand for it in this household." Scoldingly, I wagged my finger at him.

"Now-," Mr. Stein started real slow, "you know what? You are 
right, Mrs. Frank. You are ab-so-lute-ly right. I am so sorry I did so and if you'll excuse me, I must immediately head off to church to confess my most heinous sin." With that Mr. Stein ran off to his car without an answer, started her up, and drove off to church. As he did, I waved goodbye and he went off on his righteous path. His car finally out of sight, I went off to help my husband down from the truck, being careful not to stick him with the knife I mindlessly brought out from the kitchen in the frenzy Mr. Stein caused. 
Miller 
FORBES \& FIFTH 